\title{
Prevalence of Mutations in Basal Core Promoter and Precore Region of Hepatitis B Virus in Vaccinated and Nonvaccinated Individuals of the Aboriginal Nicobarese Tribe of Car Nicobar Island, India
}

\author{
Haimanti Bhattacharya ${ }^{a, b}$ Debdutta Bhattacharya ${ }^{a, c}$ Muruganandam Nagarajan ${ }^{a}$ \\ Rajesh Reesu ${ }^{a}$ Subarna Roy ${ }^{\text {a, c }}$ Purushottaman Sugunan Attayur ${ }^{a}$ \\ ${ }^{a}$ Regional Medical Research Centre (ICMR), Port Blair, ${ }^{b}$ Dr. Prabhakar Kore Basic Science Research Centre, \\ KLE University, Belgaum, and ${ }^{\mathrm{C}}$ Regional Medical Research Centre (ICMR), Nehru Nagar, Belgaum, India
}

\section{Key Words}

Hepatitis B virus - Basal core protein . Precore gene -

Mutation · Nicobarese $\cdot$ Aboriginal $\cdot$ Hepatocellular

carcinoma $\cdot$ Cirrhosis

\begin{abstract}
The aim of this study was to explore the prevalence of basal core promoter $(B C P)$ and precore gene $(\mathrm{PC})$ mutations in hepatitis $B$ virus (HBV) isolates among the Nicobarese tribe and their relationship with genotypes and $\mathrm{HBeAg}$ status. A total of 726 blood samples were collected from two villages of the Car Nicobar Island where mass vaccination was performed in the year 2000. HBV DNA was isolated and the BCP and $P C$ regions were amplified and sequenced directly. The samples positive for $\mathrm{HBV}$ DNA were tested for $\mathrm{HBsAg}, \mathrm{HBeAg}$ and anti-HBe. Among the 211 and 515 samples collected from vaccinated and nonvaccinated persons, 16 and 82 were positive for HBV DNA, respectively. Among the vaccinated individuals, only 1 had a mutation in both the BCP and PC gene. Among the nonvaccinated subjects, $3(4.5 \%)$ had an A1762T mutation, 8 (12.1\%) had a G1764A mutation, 11 (16.7\%) had a G1896A mutation and 4 (6.1\%) had a G1899A
\end{abstract}

mutation. The HBeAg-negative subjects had a significantly higher frequency of BCP and PC mutations than the HBeAgpositive subjects. The prevalence of a PC mutation was higher than that of a BCP mutation. The present study stresses the need for the continuous surveillance of subjects with $\mathrm{BCP}$ and $\mathrm{PC}$ mutations, as the mutations may contribute to the progression of liver disease.

(c) 2014 S. Karger AG, Basel

\section{Introduction}

Over 350 million people worldwide are infected chronically with hepatitis B virus (HBV), of whom 250 million reside in Asia [1,2]. HBV infection is associated with different clinical outcomes and leads to a chronic carrier state in 5-10\% of people infected in adult life and $85-90 \%$ of those infected in infancy [3]. HBV replicates by reverse transcriptase that lacks proofreading function. As a result, $\mathrm{HBV}$ exhibits a higher rate of mutation than most DNA

H. Bhattacharya and D. Bhattacharya contributed equally to this work.

Dr. Purushottaman Sugunan Attayur

Regional Medical Research Centre (ICMR)

Department of Health Research, Government of India, Post Bag No. 13

Port Blair 744101 (India)

E-Mail sugunanap@icmr.org.in 
viruses. Although development of mutation is constrained due to overlapping reading frames, mutations have been described in all genes. Mutations in the precore (PC)/core gene and basal core promoter $(\mathrm{BCP})$ regions are associated most frequently with viral persistence and clinical course of chronic hepatitis [4]. The PC open reading frame of HBV codes for the protein HBeAg. The presence of $\mathrm{HBeAg}$ in the serum of an individual is associated with active viral replication and is a highly infective stage. Subsequently, there is a loss of $\mathrm{HBeAg}$ from the serum, and the subject undergoes seroconversion to anti-HBe. Usually these parameters indicate a decrease of viral replication and remission of liver disease. However, HBV variants have been described that do not produce HBeAg despite continuing replication of infectious virions. The most common variant has a G-to-A transition at nucleotide (nt) 1896 of the $\mathrm{PC}$ region, converting codon 28 from that coding for tryptophan to a stop codon (TGG to TAG) [5]. HBV strains with this mutation do not produce HBeAg at all, and such strains might get selected over nonmutant strains. The core promoter region regulates the transcription of the $\mathrm{PC}$ region. A double mutation at nt 1762-1764 changing AGG to TGA in the BCP region (BCP mutation) has been suggested to downregulate $\mathrm{HBeAg}$ production. This mutation is thought to be associated with enhanced viral replication and has been found during chronic infection [6]. In a cross-sectional study, both the BCP mutations and the PC A1896 mutations were found to be highly and equally significant for the HBeAg-negative phenotype displayed [7]. Due to the requirement of base pairing at the pregenomic RNA level, the presence of an A1896 mutation is thought to be restricted to genotypes that have a T1858, as in the case of genotypes B, C, D and $\mathrm{E}$. The absence of this mutation in genotypes $\mathrm{A}$ and $\mathrm{F}$ has also been attributed to the presence of $C$ at nt $1858[8,9]$. In view of these clinical implications of the $\mathrm{PC}$ and $\mathrm{BCP}$ regions of $\mathrm{HBV}$, it was considered necessary to know the prevalence of these mutations among HBeAg-negative chronic HBV carriers among the Nicobarese, a tribe with a very high HBV carrier rate. The Andaman and Nicobar Islands, a Union Territory of India, is the home of six heritage/traditional tribes, constituting about $10 \%$ of the total population of these islands. Hepatitis B infection is highly endemic among these tribes [10]. The epidemiology of HBV infection among Nicobarese (a Mongoloid tribe that constitute more than $98 \%$ of the tribal population of the islands) appears to be unique with a high prevalence of the chronic carrier state $(22.2 \%)$ and a comparable proportion of the population (26.3\%) positive for anti-HBs [11]. Considering the high endemicity of
HBV infection among these aboriginal tribes, a pilot project of mass hepatitis B vaccination was initiated in the year 2000 in two villages of the Car Nicobar Island inhabited exclusively by Nicobarese [12]. More than $95 \%$ of the vaccinated people developed an anti-HBs antibody titer of more than $10 \mathrm{mIU} / \mathrm{ml}$, indicating seroprotection after the third dose of vaccination, but the proportion of seroprotected people dropped to $85.5 \%$ after 3 years and stayed at the same level 5 years after the vaccination $[13,14]$. The present study is a part of the follow-up study on the efficacy of the vaccination 10 years later. This is the first study of its kind done on this tribal community of India, which has a very high endemicity of hepatitis B.

\section{Subjects and Methods}

\section{Study Subjects}

A total of 726 blood samples were collected from two villages of the Car Nicobar Island. These 726 samples included 211 samples from individuals who belonged to the cohort that participated in the vaccination study in 2000 as part of the pilot project of mass vaccination and 515 samples were from individuals belonging to the nonvaccinated cohort. Informed consent was obtained from the subjects/guardians prior to collection of samples. Serum was separated from the blood samples and brought to the laboratory of RMRC, Port Blair, maintaining cold chain conditions and stored at $-86^{\circ}$ until processed. An attempt to isolate HBV DNA was made for all of the samples. The samples positive for HBV DNA by PCR were tested for $\mathrm{HBsAg}$, anti-HBs, anti-HBc, $\mathrm{HBeAg}$ and anti-HBe using commercially available enzyme-linked immunosorbent assay kits (General Biologicals Corporation, Hsin Chu, Taiwan).

\section{Isolation of HBV DNA and Amplification of the Surface Gene,} $B C P$ and $P C$ Regions

DNA was isolated from $200-\mu$ l serum samples by phenol/isoamyl alcohol/chloroform extraction after incubation with proteinase K. Extracted DNA was subjected to HBV detection by nested PCR of the surface (S) gene following a published protocol $[15,16]$. Extracted DNA was subjected to nested PCR using two sets of primers as described by Kumar et al. [17]. Polymerase chain reaction (PCR) was performed on $5 \mu \mathrm{l}$ of DNA extract in a $50-\mu \mathrm{l}$ reaction mix containing a final concentration of $10 \mathrm{mM}$ Tris- $\mathrm{HCl}(\mathrm{pH}$ 8.3), $50 \mathrm{mM} \mathrm{KCl}, 1.5 \mathrm{mM} \mathrm{MgCl}_{2}, 0.25 \mu \mathrm{M}$ each of the $4 \mathrm{dNTPs}$, $2.5 \mathrm{U}$ Taq DNA polymerase (Banglore Genei, Bangalore, India) and $0.6 \mathrm{mM}$ each of the primers. First-round PCR with the help of outer primers P1 (5'-GTT GCA TGG AGA CCA CCG TGA AC$\left.3^{\prime}\right)$ and P2 (5'-CTT CTG CGA CGC GGC GAT GGA GA-3') was carried out with initial denaturation at $94^{\circ}$ for $3 \mathrm{~min}$, followed by 30 cycles of $94^{\circ}$ for $1 \mathrm{~min}, 60^{\circ}$ for $1 \mathrm{~min}$ and $72^{\circ}$ for $1 \mathrm{~min} 30 \mathrm{~s}$, followed by primer extension at $72^{\circ}$ for $7 \mathrm{~min}$. Second-round PCR using $5 \mu \mathrm{l}$ of the first PCR product with the help of inner primers P3 (5'-CAT AAG AGG ACT CTT GGA CT- $\left.3^{\prime}\right)$ and P4 (5'-GGC GAG GGA GTT CTT CTT C-3') was performed with initial denaturation at $94^{\circ}$ for $3 \mathrm{~min}$, followed by 30 cycles of $94^{\circ}$ for $1 \mathrm{~min}, 55^{\circ}$ for $1 \mathrm{~min}$ and $72^{\circ}$ for $1 \mathrm{~min} 30 \mathrm{~s}$. A single cycle for primer extension was done at $72^{\circ}$ for $7 \mathrm{~min}$. 
Table 1. Details of the samples with BCP and PC mutations in $\mathrm{HBV}$ isolates

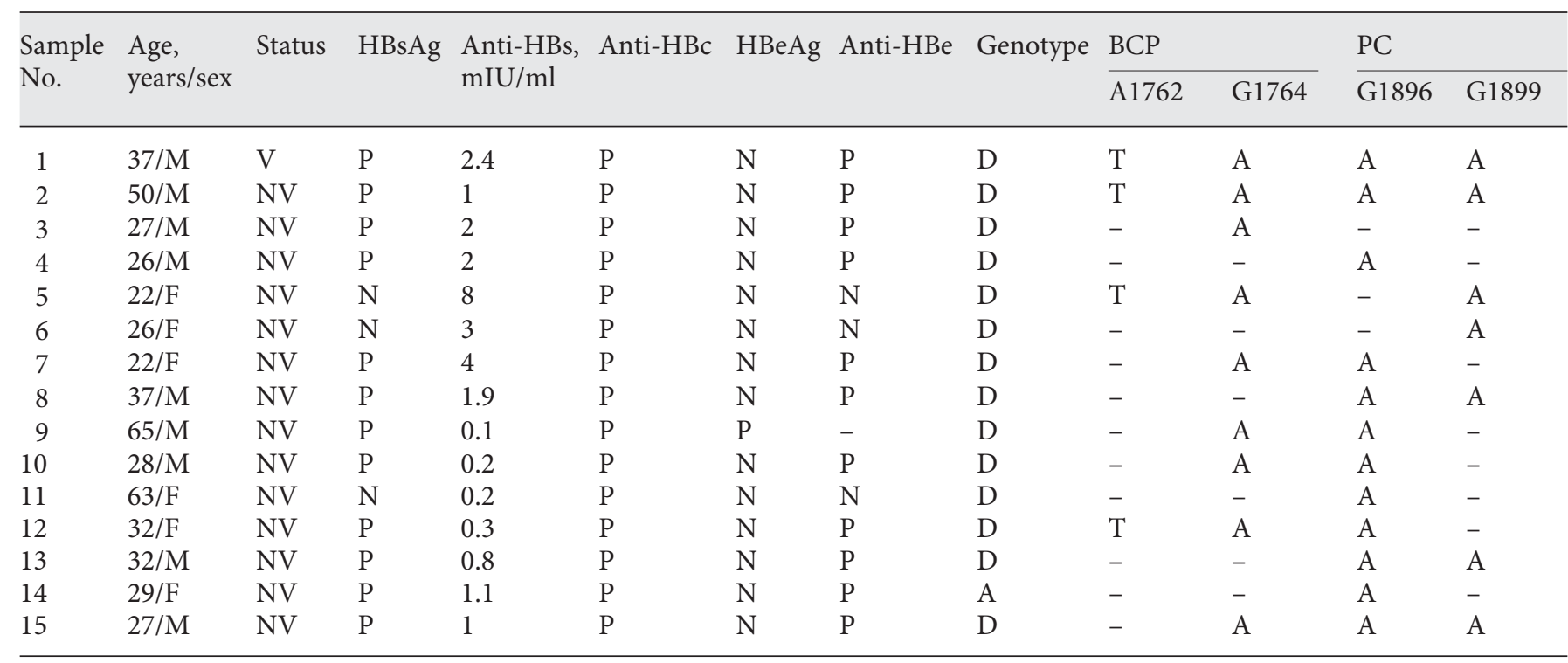

$\mathrm{V}=$ Vaccinated $\mathrm{NV}=$ nonvaccinated $\mathrm{P}=$ positive $; \mathrm{N}=$ negative.

DNA Sequencing

PCR primers were used for direct sequencing of the amplified DNA from both directions using the Big Dye terminator cycle sequencing ready reaction kit (Applied Biosystems, Foster City, Calif., USA) in a 3130 Automated DNA Sequencer (Applied Biosystems). Mutations were recorded only when detected in both the forward and reverse sequences.

Genotyping, BCP and PC mutant analysis were carried out by sequence comparison with other known sequences from different HBV genotypes as performed using MEGA5 [18] and SeqScape software (Applied Biosystems).

\section{HBV Genotyping}

Genotyping of HBV was performed on the basis of phylogenetic relationship taking 345 base pair sequences of part of the $S$ gene along with representative reference sequences from different genotypes as described earlier for $\operatorname{HBV}[19,20]$.

\section{Statistical Analysis}

Data was compared and statistical significance was tested using Epi Info 7 software (www.cdc.gov/epiinfo/). p $<0.05$ was considered statistically significant.

\section{Results}

Among the 211 samples from vaccinated persons, 16 (7.6\%, 95\% CI: 4.4, 12.0) were positive for HBV DNA, while among the 515 samples from nonvaccinated persons, 82 (15.9\%, 95\% CI: $12.9,19.4)$ were positive. Thus, among the total number of 726 subjects, 98 (13.5\%, 95\%
CI: 11.1, 16.2) were positive for HBV DNA. Bidirectional sequencing of BCP and PC genes was successfully achieved for 82 (82/98) samples positive for HBV DNA, which included 16 from vaccinated subjects and 66 from nonvaccinated subjects. Further analysis presented here is confined to these 82 subjects in whom sequencing of the $\mathrm{BCP}$ and $\mathrm{PC}$ gene was successful. The few mutations that were found in the $\mathrm{BCP}$ and $\mathrm{PC}$ region were clustered at nt positions 1762, 1764, 1896 and 1899.

Out of these $82 \mathrm{HBV}$ DNA-positive subjects, 71 (86.6\%) were negative for HBeAg, of which 42 (out of 71; $59.2 \%)$ were positive for anti-HBe. Among the 82 samples, 35 (42.7\%) were positive for HBsAg. All the samples detected with a mutation in either of BCP, PC or both, except 3, were found to be HBsAg positive (table 1). Out of the 71 subjects negative for $\mathrm{HBeAg}, 27$ (38\%) were positive for HBsAg.

\section{Mutations among Vaccinated Individuals}

All of the 16 isolates from vaccinated individuals whose BCP/PC gene was sequenced had T at nt 1858 . Only 1 (6.3\%) sample, obtained from a 37-year-old male, had mutations in both the BCP and PC region. He was positive for $\mathrm{HBsAg}$ and anti-HBe, but negative for $\mathrm{HBeAg}$. The anti-HBs titer of the sample was $2.4 \mathrm{mIU} / \mathrm{ml}$ (subject 1 in table 1). The HBV isolate was classified into genotype D (fig. 1). 


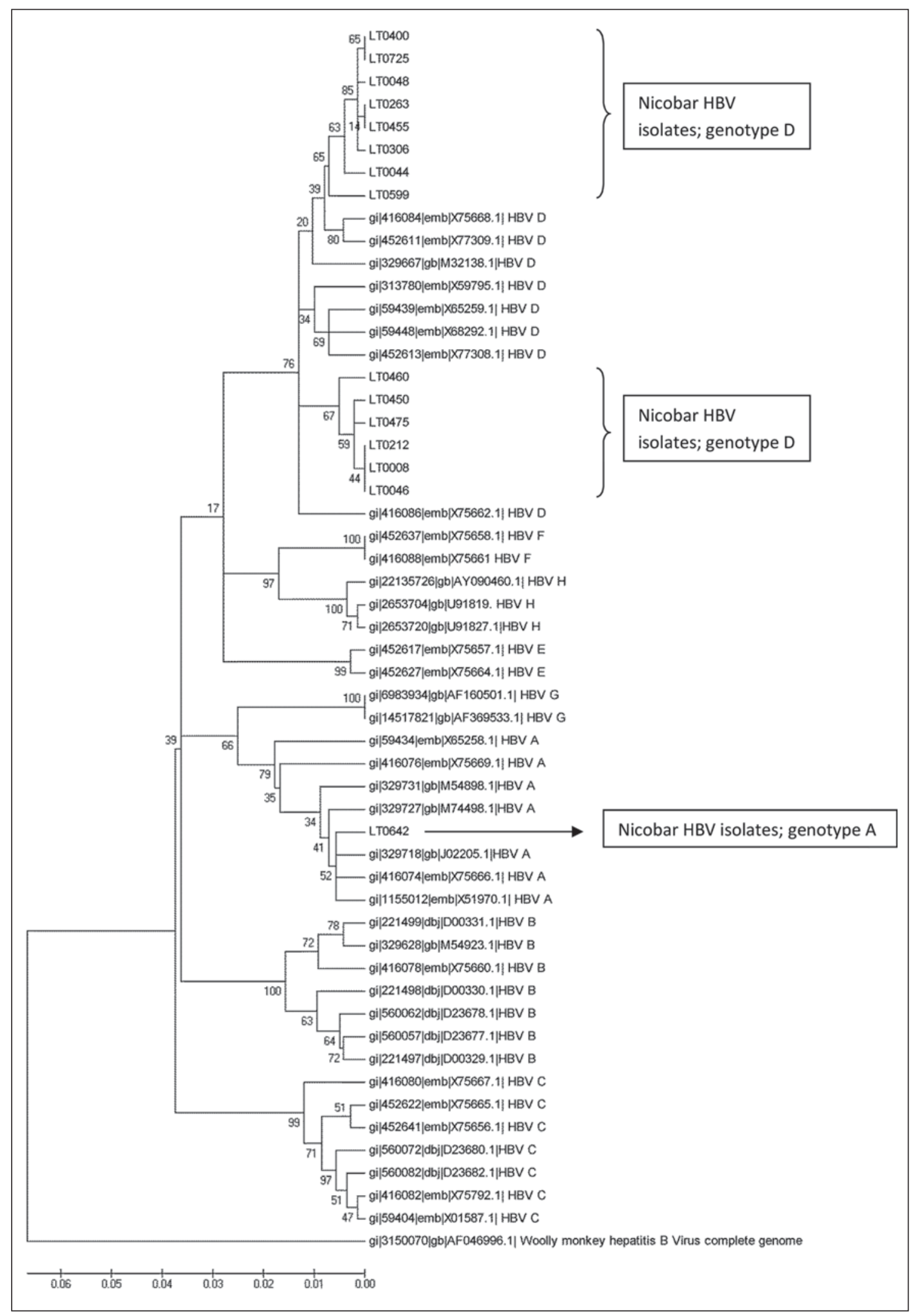

Fig. 1. Phylogenetic analysis of the partial $S$ gene showing the genotype of HBV with $\mathrm{BCP}$ and PC mutations. 
Table 2. Demographic data in with respect to the PC and BCP mutations in HBV among the nonvaccinated subjects

\begin{tabular}{|c|c|c|c|c|c|}
\hline Variables & Total & $\mathrm{HBeAg}(+)$ & HBeAg (-) & Anti-HBe ${ }^{1}(+)$ & Anti-HBe ${ }^{1}(-)$ \\
\hline \multicolumn{6}{|l|}{ Age group } \\
\hline $0-9$ years & $1(1.5)$ & $0(0)$ & $1(100)$ & $0(0)$ & $1(100)$ \\
\hline $10-19$ years & $4(6.1)$ & $1(25.0)$ & $3(75.0)$ & $0(0)$ & $3(75.0)$ \\
\hline $20-29$ years & $17(25.7)$ & $2(11.8)$ & $15(88.2)$ & $11(64.7)$ & $4(23.5)$ \\
\hline $30-39$ years & $12(20.4)$ & $2(16.6)$ & $10(83.4)$ & $9(75.0)$ & $1(8.3)$ \\
\hline $40-49$ years & $10(15.2)$ & $1(10.0)$ & $9(90.0)$ & $5(50.0)$ & $4(40.0)$ \\
\hline $50-59$ years & $13(19.7)$ & $3(23.1)$ & $10(76.9)$ & $8(61.5)$ & $2(15.4)$ \\
\hline 60 years and above & $9(13.6)$ & $2(22.2)$ & $7(77.8)$ & $2(22.2)$ & $5(55.6)$ \\
\hline \multicolumn{6}{|l|}{ Gender } \\
\hline Male & $30(39.8)$ & $8(26.7)$ & $22(73.3)$ & $15(50.0)$ & $15(50.0)$ \\
\hline Female & $36(60.2)$ & $2(5.5)$ & $34(94.5)$ & $20(55.6)$ & $16(44.4)$ \\
\hline HBV DNA positive by sequencing & 66 & $11(16.7)$ & $55(83.3)$ & $35(53.0)$ & $20(30.3)$ \\
\hline \multicolumn{6}{|l|}{ Mutation } \\
\hline \multicolumn{6}{|l|}{ In BCP } \\
\hline A1762T & $3(4.5)$ & $0(0.0)$ & $3(5.5)$ & $2(5.7)$ & $1(5.0)$ \\
\hline G1764A & $8(12.1)$ & $1(9.1)$ & $7(12.7)$ & $6(17.1)$ & $1(5.0)$ \\
\hline \multicolumn{6}{|l|}{ In $\mathrm{PC}$} \\
\hline $1858 \mathrm{~T}$ & $65(98.5)$ & $11(100)$ & $54(98.2)$ & $34(51.5)$ & $20(100)$ \\
\hline $1858 \mathrm{C}$ & $1(1.5)$ & $0(0.0)$ & $1(1.8)$ & $1(2.8)$ & $0(0.0)$ \\
\hline G1896A & $11(16.7)$ & $1(9.1)$ & $10(18.2)$ & $9(25.7)$ & $1(5.0)$ \\
\hline G1899A & $4(6.1)$ & $0(0.0)$ & $4(7.3)$ & $2(5.7)$ & $2(10.0)$ \\
\hline In $\mathrm{BCP}+\mathrm{PC}$ & $7(10.6)$ & $1(9.1)$ & $6(11.0)$ & $5(14.3)$ & $1(5.0)$ \\
\hline
\end{tabular}

Data in parentheses indicate percentages. ${ }^{1}$ Samples positive for $\mathrm{HBeAg}$ were not tested for anti-HBe, i.e. only samples negative for HBeAg were subjected to anti-HBe testing.

\section{Mutations among Nonvaccinated Individuals}

\section{BCP Mutation}

Among the 66 nonvaccinated subjects whose BCP/PC gene was sequenced, 3 (4.5\%) had an $\mathrm{A} 1762 \mathrm{~T}$ mutation and $8(12.1 \%)$ had a G1764A mutation. A total of 3 (4.5\%) had both A1762T and G1764A mutations. None of the HBeAg-positive samples had an A1762T mutation. Both $\mathrm{A} 1762 \mathrm{~T}$ (5.5\% vs. $0 \% ; \mathrm{p}=0.4278)$ and $\mathrm{G} 1764 \mathrm{~A}(12.7 \%$ vs. $9.1 \% ; \mathrm{p}=0.7358)$ mutations were observed to be not significantly different in subjects with an $\mathrm{HBeAg-negative}$ status that in those who were $\mathrm{HBeAg}$ positive (table 2). These mutations were also found to be higher in antiHBe-positive cases than in anti-HBe-negative cases.

\section{PC Mutation}

Among the 66 nonvaccinated subjects, $11(16.7 \%)$ had a G1896A mutation and $4(6.1 \%)$ had a G1899A mutation. A total of 4 (6.1\%) HBV isolates had both G1896A and G1899A mutations. One of the HBeAg-positive samples had a G1896A mutation, but none of the HBeAgpositive samples had a G1899A mutation. Both G1896A
(18.2 vs. $9.1 \% ; \mathrm{p}=0.4601)$ and $\mathrm{G} 1899 \mathrm{~A}$ (7.3 vs. $0 \% ; \mathrm{p}=$ 0.3560 ) mutations were observed to be not significantly different in $\mathrm{HBeAg}$-negative subjects compared to HBeAg-positive individuals (table 2). These mutations were found to be more frequent in anti-HBe-positive cases than in anti-HBe-negative cases. Two HBV isolates with a single mutation in the $\mathrm{PC}$ region were negative for HBsAg (table 2).

\section{Both BCP and PC Mutations}

The presence of both BCP and PC mutations were observed in $7(10.6 \%)$ of the cases and was found to be not significantly different in $\mathrm{HBeAg}$-negative cases compared to $\mathrm{HBeAg}$-positive cases (11 vs. 9.1\%; $\mathrm{p}=0.8581$ ). One $\mathrm{HBV}$ isolate with both $\mathrm{BCP}$ and $\mathrm{PC}$ mutations was negative for HBsAg.

\section{C1858T Mutation}

In the present study, 65 isolates had $\mathrm{T}$ at nt 1858 and 1 had C. Among these 65 isolates with T at nt 1858, 64 belonged to the $\mathrm{D}$ genotype and 1 to the A genotype. The 
isolate with C at nt 1858 was of the D genotype. Demographic data in respect to the BCP and PC mutations in $\mathrm{HBV}$ among the nonvaccinated subjects is provided in table 2. No mutation was detected at nt 1814 and 1862 in any of the samples. All of the individuals harboring a mutation either in $\mathrm{BCP} / \mathrm{PC}$ region or both were nonseroprotected (anti-HBs titer $\leq 10 \mathrm{mIU} / \mathrm{ml}$ ) and anti-HBc positive.

\section{Discussion}

The BCP (nt 1744-1804), residing in the overlapping X open reading frame region, controls transcription of both PC and core regions. PC mutations frequently occur temporally related to core gene mutations/deletions. A variety of $\mathrm{PC} /$ core mutants have been described in various parts of the world and are known to be associated with increased risk of hepatocellular carcinoma (HCC) as well as the progression of liver diseases [21-23]. In the present study, BCP mutations A1762T and G1764A were observed in 5.5 and $12.7 \%$ of the HBeAg-negative subjects. PC mutations G1896A and G1899A were observed in 18.2 and $7.3 \%$ of the HBeAg-negative subjects, which is slightly lower than observed in earlier studies $[21,22,24]$. A double-mutation in the BCP region was observed in $4 \mathrm{HBeAg-negative} \mathrm{in-}$ dividuals, which includes 1 vaccinated individual. The anti-HBs titer of the vaccinated individual with BCP and PC mutations was $\leq 10 \mathrm{mIU} / \mathrm{ml}$, so there is a probability of having been reinfected with $\mathrm{HBV}$. The HBeAg-negative subjects had a significantly higher frequency of mutation in both BCP and PC nucleotides than HBeAg-positive subjects. Earlier studies have also shown a high prevalence of $\mathrm{BCP}$ and $\mathrm{PC}$ mutations in $\mathrm{HBeAg}$-negative individuals $[21,24,25]$. However, $1 \mathrm{HBeAg}$-positive individual had a G1896A mutation. A study conducted in Germany showed the presence of G1896A mutations in $2.2 \%$ of the HBeAgpositive subjects [26].

Changes at positions 1762 and 1764 have been described to be especially common in subjects with C1858 $[8,27]$, but in the present study the presence of such mutations was observed in subjects with T1858. The majority of the HBV isolates in the present study was genotype $\mathrm{D}$ with $\mathrm{T}$ at $\mathrm{nt} 1858$. The same finding was observed in a study conducted in Brazil [28]. T1858 associated with genotypes $\mathrm{A}, \mathrm{C}$ and $\mathrm{D}$ had been found as well in a survey in the United Arabic Emirates [29]. In the study conducted in Brazil, PC mutations were observed to be more frequently associated with genotype D of HBV [28].

Among the 82 individuals positive for HBV DNA, 35 were HBsAg positive. The rest were positive for either an-
ti-HBs or anti-HBc indicating occult HBV infection. Occult HBV infection is a condition which may be defined as serologically undetectable hepatitis B surface antigen (HBsAg-ve), despite the presence of circulating HBV DNA with or without serological markers of a previous infection (anti-HBc and/or anti-HBs positive) [17, 30]. Core gene mutations are epidemiologically associated with disease activity, whereas the PC stop mutation may be an innocent bystander. In contrast, the double mutations in the BCP downregulate HBeAg expression and are likely to increase viral replication with enhanced disease activity [4]. Mutation G1896A in the PC region leading to a G-to-A shift could induce a stop codon and subsequently suppress the expression of HBeAg [5]. Though this would stop the production of $\mathrm{HBeAg}$, the HBV DNA would still be synthesized and eventually contribute to the progression of liver disease to a more advanced stage [16]. It was once reported that G1896A correlated with severe forms of liver diseases [31]. There is strong epidemiological evidence that a PC A1896 mutation as well as T1762 and A1764 of BCP are associated with fulminant hepatitis [32]. It was suggested that the fulminant course was due to either a vigorous immune response of the host or to high levels of HBV DNA or to high transcription efficiency of the virus [27]. In our HBV isolates, all of the BCP and $\mathrm{PC}$ mutations were observed in genotype $\mathrm{D}$ and only G1896A was observed in genotype A. Genotype D was earlier found to be the predominant genotype of HBV circulating among these tribal populations of India [15]. There are therapeutic implications of this finding as subjects with genotype D have more severe disease [33]. Earlier reports also indicated a significant correlation between BCP mutations of HBV and HCC [34].

The present study is the first of its kind to report the prevalence of these mutations among the Nicobarese tribe living in the islands where hepatitis B is highly endemic. In contrast to an earlier study carried out in India [24], the majority of the HBV isolates in our study were of genotype $\mathrm{D}$ with $\mathrm{T}$ at nt 1858 , in which the prevalence of a PC stop mutation is higher than that of a BCP mutation. The detection of BCP and PC mutations in vaccinated individuals is of grave concern as it is likely to increase viral replication and enhance disease activity [4].

\section{Conclusions}

Although there is no conclusive evidence for association of these mutations with severity of complications, the present study stresses the need for the continuous 
surveillance of these subjects with BCP and PC mutations as they may contribute to the progression of liver disease to a more advanced stage. Frequent examination of individuals with chronic HBV infections for the presence of these mutations may be useful for identifying individuals who require preventive antiviral treatment and for the prediction of development of HCC. However, the wide range of chronic liver disease, from inactive carrier to liver cirrhosis and HCC, cannot be explained completely by the presence of PC and core variants. There may be an interactive mechanism between host genetic factors and virus variation within the core protein or other proteins. The exact clinical relevance of these variants needs further investigation. Future studies should focus on interactions of these HBV mutations with host factors, as well as the development of high throughput methods for the detection of HBV mutations for the prediction of HCC.

\section{Acknowledgement}

The authors thank the Indian Council of Medical Research for providing financial grants for the study. The authors are thankful to the Tribal Council and the village captains of Tamaloo and Big Lapathy, Car Nicobar Island, for their extensive support and cooperation. The authors are also thankful to the Lady Tata Memorial Trust for providing a Junior Scholarship to H.B. The authors are thankful to Mr. D.R. Guruprasad and Ms. Sylvia Frank for providing field assistance. The study was supported by the intramural funds from the Indian Council of Medical Research. No external funds were received.

\section{Ethics Approval}

The study was cleared by the institutional Ethics Committee.

\section{Disclosure Statement}

The authors do not have any commercial or other associations that may pose a conflict of interest.

\section{References}

1 Magnius L, Norder H: Subtypes, genotypes and molecular epidemiology of the hepatitis $B$ virus as reflected by sequence variability of the S-gene. Intervirology 1995;38:24-34.

2 Kao JH, Chen DS: Global control of hepatitis B virus infection. Lancet Infect Dis 2002;2: 395-403.

3 Gust I, Crowe S: The global importance of viral hepatitis. Clin Trop Med Commun Dis 1986;1:281-301.

-4 Hunt CM, McGill JM, Allen MI, Condreay LD: Clinical relevance of hepatitis B virus mutations. Hepatol 2000;31:1037-1044.

5 Carman WF, Jacyna MR, Hadziyannis S, Karayiannis $\mathrm{P}, \mathrm{McG}$ arvey $\mathrm{MJ}$, Makris A, Thomas HC: Mutation preventing formation of hepatitis $\mathrm{B}$ e antigen in patients with chronic hepatitis B infection. Lancet 1989;2:588-591.

-6 Buckwold VE, Xu Z, Chen M, Yen TS, Ou JH: Effects of a naturally occurring mutation in the hepatitis B virus basal core promoter on precore gene expression and viral replication. J Virol 1996;70:5845-5851.

7 Kidd-Ljunggren K, Oberg M, Kidd AH: Hepatitis $\mathrm{B}$ virus $\mathrm{X}$ gene 1751 to 1764 mutations: implications for HBeAg status and disease. J Gen Virol 1997;78:1469-1478.

-8 Lindh M, Andersson AS, Gusdal A: Genotypes, nt 1858 variants, and geographic origin of hepatitis B virus - large-scale analysis using a new genotyping method. J Infect Dis 1997; 175:1285-1293.

Prevalence of BCP and PC Mutations of $\mathrm{HBV}$ in the Nicobarese Tribe, India
-9 Li J, Buckwold VE, Hon MW, Ou JH: Mechanism of suppression of hepatitis B virus precore RNA transcription by a frequent double mutation. J Virol 1999;73:1239-1244.

10 Murhekar MV, Murhekar KM, Das D, Arankalle VA, Sehgal SC: Prevalence of hepatitis B infection among the primitive tribes of Andaman and Nicobar Islands. Indian J Med Res 2000;111:199-203.

-11 Murhekar MV, Murhekar KM, Arankalle VA, Sehgal SC: Epidemiology of hepatitis B infection among the Nicobarese - a Mongoloid tribe of the Andaman and Nicobar Islands, India. Epidemiol Infect 2002;128:465-471.

12 Murhekar MV, Murhekar KM, Arankalle VA, Sehgal SC: Immune response to an indigenously developed hepatitis B (Shanvac-B) vaccine in a tribal community of India. Vaccine 2002;20:3431-3435.

13 Murhekar MV, Murhekar KM, Sehgal SC: Hepatitis $\mathrm{B}$ vaccination in a hyper-endemic tribal community from India: assessment after three years. Vaccine 2004;23:399-403.

14 Sugunan AP, Bhattacharya H, Bhattacharya D, Mandal A, Ghosal SR, Rao RC, Sugunan AP: The impact of hepatitis B immunization among the Nicobarese tribe - antibody titres and seroprotection five years after vaccination. Indian J Med Res 2014;139:427-430.

15 Arankalle VA, Murhekar KM, Gandhe SS, Murhekar MV, Ramdasi AY, Padbidri VS, Sehgal SC: Hepatitis B virus: predominance of genotype $\mathrm{D}$ in primitive tribes of the Andaman and Nicobar islands, India (1989-1999). J Gen Virol 2003;84:1915-1920.
16 Chen BF, Liu CJ, Jow GM, Chen PJ, Kao JH, Chen DS: High prevalence and mapping of pre-S deletion in hepatitis B virus carriers with progressive liver diseases. Gastroenterology 2006;130:1153-1168.

17 Kumar GT, Kazim SN, Kumar M, Hissar S, Chauhan R, Basir SF, Sarin SK: Hepatitis B virus genotypes and hepatitis $B$ surface antigen mutations in family contacts of hepatitis $B$ virus infected patients with occult hepatitis B virus infection. J Gastroenterol Hepatol 2009;24:588-598.

18 Tamura K, Peterson D, Peterson N, Stecher G Nei M, Kumar S: MEGA5: molecular evolutionary genetics analysis using maximum likelihood, evolutionary distance, and maximum parsimony methods. Mol Biol Evol 2011;28:2731-2739.

-19 Norder H, Couroucé AM, Coursaget P, Echevarria JM, Lee SD, Mushahwar IK, Robertson $\mathrm{BH}$, Locarnini S, Magnius LO: Genetic diversity of hepatitis B virus strains derived worldwide: genotypes, subgenotypes, and $\mathrm{HBsAg}$ subtypes. Intervirology 2004;47:289-309.

20 Banerjee A, Kurbanov F, Datta S, Chandra PK, Tanaka Y, Mizokami M, Chakravarty R: Phylogenetic relatedness and genetic diversity of hepatitis B virus isolates in Eastern India. J Med Virol 2006;78:1164-1174.

21 Okamoto H, Tsuda F, Akahane Y, Sugai Y, Yoshiba M, Moriyama K, Tanaka T, Miyakawa Y, Mayumi M: Hepatitis B virus with mutations in the core promoter for an e antigennegative phenotype in carriers with antibody to e antigen. J Virol 1994;68:8102-8110. 
-22 Chandra PK, Banerjee A, Datta S, Chakravarty R: G1862T mutation among hepatitis B virus-infected individuals: association with viral genotypes and disease outcome in Kolkata, Eastern India. Intervirology 2007;50:173180.

23 Liao Y, Hu X, Chen J, Cai B, Tang J, Ying B, Wang H, Wang L: Precore mutation of hepatitis $\mathrm{B}$ virus may contribute to hepatocellular carcinoma risk: evidence from an updated meta-analysis. PLoS One 2012; 7:e38394.

24 Banerjee A, Banerjee S, Chowdhury A, Santra A, Chowdhury S, Roychowdhury S, Panda CK, Bhattacharya SK, Chakravarty R: Nucleic acid sequence analysis of basal core promoter/precore/core region of hepatitis $B$ virus isolated from chronic carriers of the virus from Kolkata, Eastern India: low frequency of mutation in the precore region. Intervirology 2005;48:389-399.

25 Parekh S, Zoulim F, Ahn SH, Tsai A, Li J, Kawai S, Khan N, Trépo C, Wands J, Tong S: Genome replication, virion secretion, and e antigen expression of naturally occurring hepatitis B virus core promoter mutants. J Virol 2003;77:6601-6612.
26 Wintermeyer P, Gerner P, Ghring S, Karimi A, Wirth S: Prevalance of hepatitis B virus precore stop codon mutation in chronically infected children. World J Gastroentrol 2006; 12:2235-2238.

27 Alexopoulou A: Mutants in the precore, core promoter, and core regions of hepatitis B virus, and their clinical relevance. Ann Gastroenterol 2009;22:13-23.

28 Sitnik R, Pinho JR, Bertolini DA, Bernardini AP, Da Silva LC, Carrilho FJ: Hepatitis B virus genotypes and precore and core mutants in Brazilian patients. J Clin Microbiol 2004;42: 2455-2460.

29 Alfaresi M, Elkoush A, Alshehhi H, Alzaabi A, Islam A: Hepatitis B virus genotypes and precore and core mutants in UAE patients. Virol J 2010;7:160.

30 Panigrahi R, Biswas A, Datta S, Banerjee A, Chandra PK, Mahapatra PK, Patnaik B, Chakrabarti S, Chakravarty R: Anti-hepatitis $\mathrm{B}$ core antigen testing with detection and characterization of occult hepatitis B virus by an in-house nucleic acid testing among blood donors in Behrampur, Ganjam, Orissa in southeastern India: implications for transfusion. Virol J 2010;7:204-210.
31 Brunetto MR, Stemler M, Bonino F, Schodel F, Oliveri F, Rizzetto M, Verme G, Will H: A new hepatitis $B$ virus strain in patients with severe anti-HBe positive chronic hepatitis B. J Hepatol 1990;10:258-261.

32 Kitano K, Kobayashi H, Hanamura M, Furuta K, Ueno M, Rokuhara A, Tanaka E, Umemura T, Kiyosawa K: Fulminant hepatitis after allogenic bone marrow transplantation caused by reactivation of hepatitis $B$ virus with gene mutations in the core promotor region. Eur J Haematol 2006;77:255-258.

33 Kao JH, Liu CJ, Chen DS: Hepatitis B viral genotypes and lamivudine resistance. J Hepatol 2002;36:303-304.

34 Thongbai C, Sa-nguanmoo P, Kranokpiruk P, Poovorawan K, Poovorawan Y, Tangkijvanich $\mathrm{P}$ : Hepatitis $\mathrm{B}$ virus genetic variation and TP53 R249S mutation in patients with hepatocellular carcinoma in Thailand. Asian Pac J Cancer Prevent 2013;14:3555-3559. 